\title{
Developing Traditional Handcraft Villages: The Determinants of Lending Decision from Binh Duong Province's Banks in Vietnam
}

\author{
Man Thi LE ${ }^{*}$, Dong Nguyen Thanh LE ${ }^{* *}$ \\ Received: November 16, 2019 Revised: December 11, 2019 Accepted: December 18, 2019
}

\begin{abstract}
Small and medium enterprises (SMEs) play a very important role in developing countries. In Vietnam, SMEs operating in the field of handicrafts, besides contributing to the economy, also tasked to maintain and develop traditional handicrafts. However, accessing loans from banks of SMEs faces many difficulties. This study explores the determinants of bank lending decision for SMEs, particular, in traditional handicrafts business. Using dataset based on a survey conducted in Binh Duong province, Vietnam, we investigated to what determinant effects for loan approval. The analytical methods used include descriptive statistics for overall assessment, principal component analysis and regression to examine determinants of lending decisions. The results indicate that company's collateral was the most positive determinant to bank lending decision, follow by company's business plan. The role of company's leader is very important for banks considers to approve credit because company's leaders experience and relationship with stakeholders as well as banks have positive relations with bank's lending decision. Agreed with previous studies, the company's financial statement and company's credit history with banks are also significant determinants for lending decision. Whereas, the business environment seam unaffected lending decision as their relations is not significant.
\end{abstract}

Keywords: SMEs, Traditional Handicraft, Lending Decision, Vietnam.

JEL Classification Code: G20, G21, R10, R11.

\section{Introduction}

less able to access and participate in the market, the ability to capture and process market information, and the ability to account is limited. Therefore, the ability to exchange and develop commodity production also has many limitations. The production practices of Vietnam households are generally still small, fragmented, mostly tied within the village framework (Nhung, Thai, Trinh, \& Phong, 2019). The number of handicraft villages in

* First Author. Associate Professor, University of Economics and Finance, Vietnam [Postal Address: 141 Dien Bien Phu Street, Ward 15, Binh Thanh District, Ho Chi Minh City, 700000, Vietnam] Email: manlt@uef.edu.vn

* * Corresponding Author. PhD Candidate, School of Business, International University, Vietnam National University, Vietnam [Postal Address: Quarter 6, Linh Trung Ward, Thu Duc District, Ho Chi Minh City, 700000, Vietnam]/ Lecturer, University of Economics and Finance, Vietnam [Postal Address: 141 Dien Bien Phu Street, Ward 15, Binh Thanh District, Ho Chi Minh City, 700000, Vietnam] Tel.: (+84) 908000232 Email: dongInt@uef.edu.vn - Copyright: Korean Distribution Science Association (KODISA)

This is an Open Access article distributed under the terms of the Creative Commons Attribution NonCommercial License (https://creativecommons.orgllicenses/by-nc/4.0/) which permits unrestricted noncommercial use, distribution, and reproduction in any medium, provided the original work is properly cited.
Vietnam is very large, together with a large demand for capital, but the current capital of these villages is restricted. According to the statistics of Vietnam Association of Craft Villages, about $40 \%$ of enterprises in traditional craft villages are currently in a state of close to bankruptcy; the remaining $60 \%$ is trying to hold on.

Difficulty in accessing capital from banks comes from many reasons: (i) Business efficiency of enterprises in craft villages is not high; (ii) Lack of transparency in operation, slow update of financial statements, so the appraisal of the use of bank loans is difficult; (iii) Lack of explanations on business and production plans, failing to meet the bank's loan procedures; (iv) Lack of collaterals, high interest rates; (v) Restrictions on management, non-specialized and parttime jobs between finance and accounting work, therefore, cash flow management is still ineffective, and no long-term cash flow plan has been developed (ASEAN, 2014). The study of the determinant of bank's approval decision for crediting traditional handicraft villages is one of the urgent issues in order to find the relations, the determinants to promote credit growth of banks and help traditional handicraft villages sustain and develop. 


\section{Literature Review and Hypothesis Development}

\subsection{Literature Review}

The study of (Coleman, 2002) pointed out that the main cause of failure for SMEs comes from the lack of financial resources. In addition, Tenev, Carlier, Chaudry, and Nguyen (2003) have stated that two financial sources exist mainly in the capital structure of SMEs including: (i) internal capital is made up of equity and (ii) external capital is mostly obtained from financial loans with credit institutions. According to Beck, Georgiadis, and Straub (2014), because the internal capital is mostly small, the SMEs are in desperate need of additional financial support from reliable external sources to develop and survive in an increasingly competitive market. Cassar and Holmes (2003) emphasized that achieving access to finance is a vital factor determining the growth and development of SMEs because they must have access to efficient financial resources before they can sustainable and develop in today's economics. In developing countries where the financial markets are relatively small and young, commercial banks are the key external source of funding for SMEs (Klonowski, 2019). However, numerous studies have shown that most SMEs face more obstacles than larger firms in accessing finance and investments (Vanauken, Ascigil, \& Carraher, 2017).

\subsection{Hypotheses Development}

Approaching from the perspective of credit supply, the researchers have learned about credit operations as well as lending policies and products for corporate customers of commercial banks in Vietnam. The survey results show that by the end of 2018, commercial banks do not have policies for credit or specialized loan products specifically applied for craft enterprises. In addition, studies on craft villages in show that the majority of craft villages are small-scale, and micro (Jamir \& Sridharan, 2017). Therefore, factors affecting the expansion of credit for handicraft enterprises are also considered on the basis of factors affecting credit expansion to SMEs. These factors are considered from the perspective of commercial banks.

From a legal perspective, commercial banks comply with the provisions of the law when considering granting credit to customers. According to the Circular 39/2016/TT-NHNN dated 30/12/2016 of the State Bank of Vietnam, to considering the legal capacity of enterprises, banks must evaluate in order to ensuring that the borrower meets the criteria: (i) has a feasible plan to use the capital, and (ii) has financial capacity to pay the debt. Therefore, the $6 \mathrm{C}$ rule is considered a common rule in credit evaluation of commercial banks, whereby appraisers look at each detail in detail, including: Character, Capacity, Cash-flow, Collateral, Conditions and Control.

In 2016, Haron and Ibrahim identified three main groups of factors influencing approval loan decisions: SMEs with good financial position, good relationship with banks and collaterals. Harvie, Narjoko, and Oum (2015) analyzed on data of 1,055 SMEs in 8 Asian countries, including Cambodia, Laos, Indonesia, Malaysia, Philippines, Thailand, China, Korea and Vietnam. The study showed that SME's access to credit is affected by the following factors: (i) business characteristics (size, number of years of operation, business lines, level of national development family, business life cycle and type of business); (ii) characteristics of the business owner (managerial experience, financial ability, managing more than one company); and (iii) past performance of the business (profitability and revenue growth)

Nguyen and Wolfe (2016) surveyed 218 people doing credit appraisal at commercial banks in Ho Chi Minh City and identified seven independent variables affecting lending decisions including: financial statement, qualifications and competencies of business owners/leaders, the integrity of the owner/leader of the business, loan relationship with the bank, credit history, relationship of the owner/business leader with related parties, collateral. Recently, a study by Boushnak, Rageb, Ragab, and Sakr (2018) has confirmed the factors affecting SME's ability to borrow bank loans: characteristics of the business owner, business - financial capacity, firm's capital size; credit bureau report, and credibility of financial statements.

Based on the government's regulations on lending rules and the results of previous studies, researchers selected 8 determinants to investigate their influence on the commercial banks' decision to grant credit to SMEs as below (see Table 1):

We developed and test following hypotheses:

H1: Company's financial statement has positively related with banks' credit approval decision.

H2: Experience and competence of business leaders have positively related with banks' credit approval decision.

H3: Credit relationship with the bank has positively related with banks' credit approval decision.

H4: Company's credit history has positively related with banks' credit approval decision.

H5: Relations of business leaders with stakeholders have positively related with banks' credit approval decision.

H6: Company's business plan has positively related with banks' credit approval decision.

H7: Company's business environment has positively related with banks' credit approval decision.

H8: Company's collateral has positively related with banks' credit approval decision. 
Table 1: Summary of variables

\begin{tabular}{|c|c|c|}
\hline No. & Determinants & Explain \\
\hline 1 & Financial Statement (FIN) & $\begin{array}{l}\text { Confidence level of figures on financial statements } \\
\text { Groups of financial indicators: liquidity, leverage, operations, profitability; } \\
\text { The level of revenue and profit growth } \\
\text { The personal support of business owners }\end{array}$ \\
\hline 2 & Experience and competence of business leaders (EXP) & $\begin{array}{l}\text { Experience in business } \\
\text { Understanding the movement and development of the market } \\
\text { Ability to select and manage the resources of the business } \\
\text { Ability to use information technology in executive and business management }\end{array}$ \\
\hline 3 & Credit relationship with the bank (CRR) & $\begin{array}{l}\text { Years of credit relationship at the bank } \\
\text { Enterprises or business owners/leaders have ever borrowed capital from the bank } \\
\text { The bank that is granting credit is the main transaction bank }\end{array}$ \\
\hline 4 & Credit history (CRH) & $\begin{array}{l}\text { Enterprises or business leaders who have outstanding loans at the bank } \\
\text { Credit information with banks } \\
\text { Overdue debt history at the bank }\end{array}$ \\
\hline 5 & Relations of business leaders with stakeholders (LDR) & $\begin{array}{l}\text { Have a good personal relationship with: } \\
\text { - Banks or financial institutions } \\
\text { - State management agencies } \\
\text { - Customers } \\
\text { - Suppliers }\end{array}$ \\
\hline 6 & Business plan (BPL) & $\begin{array}{l}\text { Business plan is evaluated: } \\
\text { - Feasible: the product is competitive } \\
\text { - Company is capable of fulfilling the plan. } \\
\text { - Effectiveness: profitable } \\
\text { - Having enough sources to repay debts }\end{array}$ \\
\hline 7 & Business environment (ENR) & $\begin{array}{l}\text { Business environment, including the main business sector of the enterprise which is } \\
\text { stable or has growth potential }\end{array}$ \\
\hline 8 & Collateral (COL) & $\begin{array}{l}\text { Collaterals have: } \\
\text { - Clear legal } \\
\text { - Liquidity } \\
\text { - Having sufficient value to guarantee a loan }\end{array}$ \\
\hline
\end{tabular}

\section{Research Methodology}

\subsection{Operationalization of Constructs and Data Collection}

This study employed a survey method, using a questionnaire to test the conceptual model and developed hypotheses. The prospective respondents were chosen from banks' credit officers of the Binh Duong province via a multistage stratified sampling. The questionnaire was developed through a thorough review of previous related literature and survey instruments. In additional, to ensure content validity, each item was measured using a 5-point Likert scale. For improving the reliability and validity of the construct a pilot survey was conducted. The respondents have been screened for eliminate missing values questionnaires. Twenty of them were excluded, resulting in a final data set with 405 observations.

\subsection{Analysis}

To test the hypotheses, the linear regression technique is conducted by using IBM SPSS software (version 25), this study applied the two-step approach for data analysis. The first step analyzed the measurement model, and the second step assessed the linear regression relationships among the latent construct. This approach was used to determine the reliability and validity of the measures before testing the relationship of the model.

\section{Results}

\subsection{Measurement Model Analysis}

To test the reliability and validity of the reflective constructs, composite reliability (CR) was measured in relation to internal reliability. Overall, 2-item was eliminated from the scale. The measurement scale remains thirty items for eight constructs. Table 2 shows that all constructs had $\mathrm{CR}$ values above 0.7 , which satisfies the suggestion of Hair No Reference (2014) to accept items with loadings of at least 0.7 . Individual item reliability was deemed acceptable because all the loadings associated with each of the scales were greater than 0.7 .

Then, convergent validity was then assessed using the average variance (AVE), which was above 0.5 , thus indicating satisfactory convergent validity. In addition to the composite reliability (CR), the average variance 
extracted (AVE) of these constructs achieved the cut-off point, indicating a satisfactory degree of reliability with ranging from 0.667 to 0.800 . This result indicates that the measurement model has demonstrated an adequate convergent validity.

On the basis of the Fornell and Larcker criterion, the square root of AVE for each construct exceeded the intercorrelations of the construct with the other constructs in the model (see Table 3).
All the ratios showed good discriminant validity properties. Both analyses confirmed the discriminated validity of all the constructs. Table 2 shows that no indicator loads were higher in an opposing construct (Hair et al., 2014). The result of the measurement model indicates that various validity and reliability criteria were satisfied. Therefore, the constructs the constructs and their measures could be adequately discriminated and appropriated to predict relevance for the associated hypotheses.

Table 2: Measurement model evaluation of first-order factors

\begin{tabular}{|c|c|c|c|c|}
\hline Constructs & No. Items & Factor loadings & CR & AVE \\
\hline Financial Statement (FIN) & 4 & $0.704-0.776$ & 0.878 & 0.556 \\
\hline Leaders experience (EXP) & 4 & $0.703-0.832$ & 0.842 & 0.572 \\
\hline Credit relations with bank (CRR) & 4 & $0.787-0.843$ & 0.884 & 0.657 \\
\hline Credit history (CRH) & 4 & $0.738-0.812$ & 0.804 & 0.613 \\
\hline Leader relationship with stakeholder (LDR) & 3 & $0.713-0.807$ & 0.822 & 0.562 \\
\hline Business plan (BPL) & 4 & $0.716-0.856$ & 0.824 & 0.628 \\
\hline Business environment (ENR) & 4 & $0.751-0.876$ & 0.881 & 0.702 \\
\hline
\end{tabular}

Note: $\mathrm{CR}=$ Composite Reliability, AVE = Average Variance Extracted.

Table 3: Discriminant validity coefficients

\begin{tabular}{|l|c|c|c|c|c|c|c|c|}
\hline & FIN & EXP & CRR & CRH & LDR & BPL & ENR & COL \\
\hline FIN & $\mathbf{0 . 7 4 6}$ & & & & & & \\
\hline EXP & 0.420 & $\mathbf{0 . 7 5 6}$ & & & & & \\
\hline CRR & 0.301 & 0.371 & $\mathbf{0 . 8 1 1}$ & & & & \\
\hline CRH & 0.457 & 0.441 & 0.496 & $\mathbf{0 . 7 8 3}$ & & & & \\
\hline LDR & 0.179 & 0.245 & 0.131 & 0.034 & $\mathbf{0 . 7 5 0}$ & & & \\
\hline BPL & 0.367 & 0.278 & 0.321 & 0.322 & 0.114 & $\mathbf{0 . 7 9 2}$ & & \\
\hline ENR & 0.311 & 0.323 & 0.373 & 0.395 & 0.208 & 0.408 & $\mathbf{0 . 8 3 8}$ & \\
\hline COL & 0.332 & 0.314 & 0.356 & 0.293 & 0.286 & 0.250 & 0.217 & $\mathbf{0 . 8 1 1}$ \\
\hline
\end{tabular}

Note: Diagonals (in bold) represent square root of the AVE.

\subsection{Regression Results}

Table 4: Bootstrap for Coefficients

\begin{tabular}{|c|c|c|c|c|c|c|c|}
\hline & \multirow{3}{*}{ Model } & \multirow{3}{*}{ B } & \multicolumn{5}{|c|}{ Bootstrap $^{a}$} \\
\hline & & & \multirow{2}{*}{ Bias } & \multirow{2}{*}{ Std. Error } & \multirow{2}{*}{ Sig. (2-tailed) } & \multicolumn{2}{|c|}{ 95\% Confidence Interva } \\
\hline & & & & & & Lower & Upper \\
\hline \multirow{9}{*}{1} & (Constant) & $-1,375$ &,- 006 &, 315 &, 000 & $-2,004$ &,- 770 \\
\hline & EXP & ,096 & ,001 &, 042 & ,024 & 014 &, 179 \\
\hline & ENR & ,031 &,- 001 & ,046 & ,491 &,- 058 &, 125 \\
\hline & $\mathrm{CRH}$ & ,091 & $-6,031 \mathrm{E}-5$ &, 033 & ,006 & 027 & , 158 \\
\hline & BPL & 237 & ,001 & 051 & 000 & , 140 & 341 \\
\hline & $\mathrm{COL}$ & ,342 & ,001 & 055 & 000 & 232 & ,454 \\
\hline & LDR & ,201 &, 002 & ,068 & ,004 & 071 & ,336 \\
\hline & CRR & ,133 & 000 & ,047 & 005 & ,041 & 223 \\
\hline & FIN & ,205 &,- 001 & 052 & ,001 & 104 & ,303 \\
\hline
\end{tabular}

a. Unless otherwise noted, bootstrap results are based on 5000 bootstrap samples 
A nonparametric bootstrapping was applied (Rutherford, Pollack, Mazzei, \& Sanchez-Ruiz, 2017) with 5000 replications to test the model (see Table 4).

The significance of the direct effects specified by the research model were evaluated (see Table 5). The results indicate that the effects lending approval decision is influenced directly by Company's collateral $(\beta=0.302$, $\mathrm{t}=5.734, \mathrm{p}<0.000)$, Business plan $(\beta=0.209, \mathrm{t}=5.559, \mathrm{p}<$
$0.000)$, Finance statement $(\beta=0.177, \mathrm{t}=3.344, \mathrm{p}<0.001)$, Leader relations with stakeholders $(\beta=0.156, \mathrm{t}=3.788$, $\mathrm{p}<0.000)$, followed by Credit relations with bank $(\beta=0.110$, $\mathrm{t}=2.809, \mathrm{p}<0.005)$, Credit history $(\beta=0.097, \mathrm{t}=2.621, \mathrm{p}<$ $0.009)$ and Leader experience $(\beta=0.083, t=2.354, p<0.019)$. As a result, hypotheses $\mathrm{H} 1, \mathrm{H} 2, \mathrm{H} 3, \mathrm{H} 4, \mathrm{H} 5, \mathrm{H} 6$, and $\mathrm{H} 8$ are supported, $\mathrm{H} 7$ are not supported from the current study.

Table 5: Path Coefficients and Hypothesis Testing

\begin{tabular}{|c|c|c|c|}
\hline Hypothesis & Relationship & Path Coefficient & Decision \\
\hline H1 & FIN -> DEC & $0.177^{* * *}$ & Supported \\
\hline H2 & EXP -> DEC & $0.083^{* * *}$ & Supported \\
\hline H3 & CRR -> DEC & $0.110^{* * *}$ & Supported \\
\hline H4 & CRH -> DEC & $0.097^{* * *}$ & Supported \\
\hline H5 & LDR -> DEC & $0.156^{* * *}$ & Supported \\
\hline H6 & BPL - DEC & $0.209^{* * *}$ & Supported \\
\hline H7 & ENR -> DEC & 0.027 & Not supported \\
\hline H8 & COL -> DEC & $0.302^{* * *}$ & Supported \\
\hline
\end{tabular}

$\mathrm{t}$ values were computed through the bootstrapping procedure with 405 cases and 5,000 samples $* * \mathrm{p}<0.05,{ }^{* * *} \mathrm{p}<0.001$ (one tail)

\subsection{Discussion}

The aim of the study was to examine key determinants on lending approval decision by banks for SMEs in traditional craft villages sector. The research results show that company's collateral is the most important to predict credit approve. This completely agreed with the findings of Nguyen and Wolfe (2016). It indicates that once banks feel guaranteed with collateral they will have strong agreed to credit. In short, it is important that SMEs should have collateral to be granted credit from banks. However, in SMEs, the collaterals are usually their houses. Additionally, in line with the previous studies by Cassar and Holmes (2003), the results reveal the important role of company's business plan and finance statement on the decision for approval lending from banks. Data has shown that the majorities of SMEs have low financial skill to report their financial statement as well as planning their business strategy. It is a critical point for SMEs to reach the funds.

The results also confirm the impacts of the leader relations with stakeholder, credit relations with banks and credit history of SMES are significant related with lending approval from bank. This finding is consistent with that of Lee, Sameen, and Cowling (2015), Nguyen and Wolfe (2016). In Vietnam, the relations of company's leaders with stakeholder, particular with banks has important role for lending approve. From the banks perspective, SMEs with good credit history is also a benchmark for lending. The leaders then will convince banks based on the company or organization's strategies. Thanks to this, both SMEs and banks will benefit and have a good partnership in terms of relationship.
On the other side, the business environment seems ineffective on the lending decision of banks. It indicates that, the banks treat SMEs in different types of handicraft equally. All of SMEs run business in handicraft have same opportunities to reach the bank lending. Last but not least, the experience of leaders or the seniority of SMEs contribute positively to the decision lending from banks. Although several factors have significant effects on bank's decision giving credit, those findings need further investigation to explore its nature.

\section{Conclusion and Implications}

This study provided several academic implications. First, based on the empirical results, the lending decision of banks for SMEs effect by seven determinants. This finding suggests that governments should focus policies on improving SMEs' ability in finance management and planning business strategies. These gaps could be reduced by the government's' packages in training the leaders/mangers of SMEs, particular in traditional handicraft. Moreover, the companies' collateral still the most determinant effects on bank's lending decision lead SMEs hard to reach the funds because of shortage fixedassets. The government and banks should give privileges to SMEs for lending without collateral. Finally, the policy makers can use this knowledge to promote competitive of SMEs.

In addition, this study offers recommendations for policy makers and managers in banks as well as in SMEs. Gaining a thorough understanding of the determinants of 
lending approval will enable the managers the light to focus. With such understanding, policy makers can improve their policies and strategies to ensure the SMEs could reach the funds and support packages from government. Inevitable, the limitations of the study should be taken into account. The present study focus on lending approval decision of bank as dependent variable. Consequently, more research is needed to explore the management abilities in SMEs. Furthermore previous studies which used the linear relationship amongst the variables were investigated. The potential non-linear relationships amongst variables can be investigated in future studies. Moreover, the current study was conducted at Binh Duong province in Vietnam which limits the findings generalizability strength to other provinces and cities.

\section{References}

ASEAN, S. (2014). Policy Index 2014: Towards Competitive and Innovative ASEAN SMEs (Eria Research Project Report). Jakarta, Indonesia: ERIA.

Beck, R., Georgiadis, G., \& Straub, R. (2014). The finance and growth nexus revisited. Economics Letters, 124(3), 382-385.

Boushnak, E., Rageb, M. A., Ragab, A. A., \& Sakr, A. M. (2018). Factors Influencing Credit Decision for Lending SMEs: A Case Study on National Bank of Egypt. Open Access Library Journal, 5(11), 1-17.

Cassar, G., \& Holmes, S. (2003). Capital structure and financing of SMEs: Australian evidence. Accounting Finance, 43(2), 123-147.

Coleman, S. (2002). Constraints faced by women small business owners: Evidence from the data. Journal of Developmental Entrepreneurship, 7(2), 151-174.

Haron, R., \& Ibrahim, K. (2016). Islamic financing in mitigating access to financing problems of SMEs in Malaysia: a survey analysis. Intellectual Discourse, 24, 387-408.
Harvie, C., Narjoko, D., \& Oum, S. (2015). Economic Integration in East Asia: Production networks and small and medium enterprises. London, England: Routledge.

Jamir, I., \& Sridharan, P. (2017). Government and institutions' role in promoting micro-enterprises: A study among handicraft entrepreneurs in Dimapur District, Nagaland. In Entrepreneurship Education (pp. 367-390). New York, NY: Springer.

Klonowski, D. (2019). How venture capitalists may impair the entrepreneurial ecosystem throughout their investment process. Paper presented at the CESifo Forum.

Lee, N., Sameen, H., \& Cowling, M. (2015). Access to finance for innovative SMEs since the financial crisis. Research policy, 44(2), 370-380.

Nguyen, S., \& Wolfe, S. (2016). Determinants of successful access to bank loans by Vietnamese SMEs: new evidence from the red river delta. The Journal of Internet Banking Commerce, 21(1), 162.

Nhung, N. H., Thai, N. Q., Trinh, B., \& Phong, N. V. (2019). Rural and Urban in Vietnam Economic Structure. International Business Research, 12(3), 3139.

Rutherford, M. W., Pollack, J. M., Mazzei, M. J., \& Sanchez-Ruiz, P. (2017). Bootstrapping: Reviewing the literature, clarifying the construct, and charting a new path forward. Group Organization Management, 42(5), 657-706.

Tenev, S., Carlier, A., Chaudry, O., \& Nguyen, Q.-T. (2003). Informality and the playing field in Vietnam's business sector. Washington DC: World Bank Publications.

Vanauken, H. E., Ascigil, S., \& Carraher, S. (2017). Turkish SMEs' use of financial statements for decision making. The Journal of Entrepreneurial Finance, 19(1), $6 . \quad$ Retrieved from: https://digitalcommons.pepperdine.edu/cgi/viewcontent. cgi? article $=1267 \&$ context $=$ jef 